\title{
АКТИВНІСТЬ СУПЕРОКСИДДИСМУТАЗИ І КАТАЛАЗИ У СТІНЦІ ТОНКОЇ КИШКИ, СЕРЦІ І ПЕЧІНЦІ ЩУРІВ ПРИ ЕКСПЕРИМЕНТАЛЬНОМУ ЗАСТОСУВАННІ КАРАГІНАНУ
}

๑О. М. Копаниця

\section{Рівненський державний базовий медичний коледж}

РЕзЮмЕ. Вступ. Одним з провідних механізмів формування синдрому органних дисфункцій при різних патологіях $\epsilon$ гіперпродукція активних форм оксигену, які запускають процеси пероксидного окиснення в органах і тканинах, віддалених від вогнища ураження [6]. Виникнення оксидативного стресу зумовлене також зниженням ефективності антиоксидантного захисту.

Мета дослідження - встановлення активності супероксиддисмутази та каталази в тканинах тонкої кишки, серця і печінки тварин при застосуванні 1 \% розчину к-карагінану.

Матеріал і методи. Дослідження проведено на 24 білих нелінійних самцях-щурах. Тваринам дослідної групи забезпечували вільний доступ до 1,0% розчину карагінану у питній воді протягом 1 місяця. У відібраних зразках тонкої кишки, серця і печінки тварин оцінювали активність супероксиддисмутази і каталази.

Результати. Встановлено, що застосування 1 \% розчину к-карагінану, розчиненого у питній воді, зумовлювало активацію ензимної ланки антиоксидантної системи захисту щурів. Встановлено зростання активності СОД у гомогенаті стінки тонкої кишки (в 1,32 раза, $\mathrm{p}<0,05)$ і печінці (в 1,30 раза, $\mathrm{p}<0,05)$. Підвищувалася також активність каталази у гомогенаті стінки тонкої кишки (в 1,18 раза, $p<0,05)$ і печінці (в 1,13 раза, $p<0,05)$. При цьому коефіцієнт антиоксидантного захисту в стінці кишки становив 1,11 ( $<<0,05)$, в міокарді - 1,0 і в печінці - 1,15 $(p<0,05)$.

Висновки. Пероральне застосування 1 \% розчину карагінану веде до статистично значимої активації ензимної ланки антиоксидантного захисту в стінці тонкої кишки і печінці щурів, що характеризується підвищенням, відповідно, активності СОД (на 31,8 \% і 29,7 \%) і каталази (на 18,3 \% і 12,9 \%), p<0,05.

КЛючовІ СЛОВА: щури; карагінан; антиоксидантний захист.

Вступ. Вітчизняними і зарубіжними дослідниками доведена актуальність застосування у технології харчових продуктів добавок, які модифікують і стабілізують їх структурно-механічні властивості, серед яких надзвичайно популярним $\epsilon$ карагінан. Незважаючи на велику кількість досліджень на тваринах, які вказують на безпечність карагінану в складі харчових продуктів [1], впродовж останніх десяти років з'явився також ряд наукових повідомлень, в яких говориться про можливість розвитку запалення в лініях кишкових клітин людини за дії Е407, шляхом зв' язування з toll-подібним рецептором 4 (TLR4), індукуючи експресію прозапальних хемокінів та цитокінів, таких, як IL-8, CCL2, IL6 та TNF- $\alpha$ [2-5]. Було також зроблено припущення, що карагінан може індукувати оксидативний стрес, що також може призвести до запалення [5].

Одним із провідних механізмів формування синдрому органних дисфункцій при різних патологіях $\epsilon$ гіперпродукція активних форм оксигену, які запускають процеси пероксидного окиснення в органах і тканинах, віддалених від вогнища ураження [6]. Виникнення оксидативного стресу зумовлене також зниженням ефективності антиоксидантного захисту.

Мета дослідження - визначити активність супероксиддисмутази та каталази в тканинах тонкої кишки, серця і печінки тварин при застосуванні $1 \%$ розчину к-карагінану.
Матеріал і методи дослідження. Дослідження проведено на 24 білих нелінійних самцяхщурах, яких утримували на стандартному раціоні віварію Тернопільського державного медичного університету імені І. Я. Горбачевського. Під час роботи дотримувалися принципів Європейської конвенції із захисту лабораторних тварин. Піддослідних щурів поділили на 2 групи: 1 - контроль (інтактні тварини), 2 - тварини, що вживали карагінан. 2 групі тварин був забезпечений вільний доступ до 1,0 \% розчину карагінану у питній воді протягом 1 місяця $[7,8]$.

Відбирали зразки стінки тонкої кишки, серця і печінки, відмивали у фізіологічному розчині. Наважки тканин по 1 г гомогенізували на льодяній бані на гомогенізаторі в буферному розчині [9]. Кількість протеїну в кожному зразку визначали за методом Лоурі [10]. У відібраних зразках визначали активність супероксиддисмутази (СОД) (КФ 1.11.1.6) і каталази (КФ 1.15.1.1).

Методика визначення активності СОД базується на вимірюванні кількості продукту окиснення адреналіну, що має поглинання в області 347 нм, утворення якого проходить за відсутності додаткових джерел генерації О2- і найбільш чутливе до СОД [11]. Гомогенат тканин готували у середовищі виділення, яке містило 0,25 М сахарози і 1 мМ ЕДТА в співвідношенні 1:9. Після центрифугування (6000 о6./Хв, 15 хв) відбирали супернатант для подальшого дослідження. Процедура 
Огляди літератури, оригінальні дослідження, погляд на проблему

проведення реакції аутоокиснення адреналіну починалася з додавання 2 мл 0,2 М карбонатного буфера $(\mathrm{pH}=10,65)$, тоді 100 мкл - 0,1\% розчину адреналіну. Розчин швидко перемішували і вимірювали величину оптичної щільності (=347 нм) через кожні 30 с протягом 5 хв. При роботі з пробою в кювету до 2 мл буфера додавали 10 мкл проби і 100 мкл 0,1 \% розчину адреналіну, перемішували і вимірювали наростання оптичної щільності, як описано вище. До контрольної проби, проти якої проводили вимірювання, не вносили адреналін. Про величину активності СОД у пробі судили за ступенем інгібування ним швидкості аутоокиснення адреналіну. Відсоток інгібування вираховували за формулою:

\% інгібування (од. ак.) = [1- (Dд / Dк)] * 100 \%,

де Dд і Dк - швидкості реакції аутоокиснення адреналіну в присутності і у відсутності проби відповідно.

Про швидкість окиснення адреналіну судили за зміною оптичної щільності.

Визначення активності каталази проводили у гомогенаті тканин після осадження мітохондрій за методом Королюка та співавт. [12]. Активність розраховували в мкмоль $\mathrm{H}_{2} \mathrm{O}_{2} /$ хв на 1 мг білка.

Отримані дані піддавали статистичній обробці $[13,14]$. Для перевірки на відповідність вибірок даних нормальному закону розподілу було застосовано розрахунок критерію Шапіро-Уілка. У зв' язку з відсутністю відповідності даних нормальному розподілу на рівні значимості $p<0,05$, рівень статистичної значущості відмінностей вибірок оцінювали за допомогою непараметричного критерію Манна-Уїтні. Відмінності вважали статистично значущими при досягнутому рівні $<<0,05$.

Результати й обговорення. Виявлено зростання активності СОД у гомогенаті стінки тонкої кишки (в 1,32 раза, $\mathrm{p}<0,05)$ і печінці (в 1,30 раза, $\mathrm{p}<0,05)$ (табл. 1). Згідно з сучасними поглядами, суперексиддисмутаза виконує не так захисну роль, оскіль- ки токсичність ї̈ субстрату супероксидного аніонрадикала не дуже висока як джерела гідроген пероксиду, в результаті супероксиддисмутазної реакції, під дією якого може спостерігатися продукція гідроксильного радикала й інактивація каталази і глутатіонпероксидази [15]. Тому висока активність СОД $\epsilon$ додатковим пошкоджувальним фактором. Крім того, зниження супероксиддисмутазної активності в тканинах, ймовірно, може бути зумовлено надлишковим утворенням гідропероксидів жирних кислот, які інгібують активність цього ензиму.

Каталаза - фермент класу оксидоредуктаз, який відновлює гідрогенпероксид до води і молекулярного кисню, компенсаторно підвищуючи коефіцієнт корисного використання екзогенного кисню в енергетичних цілях за рахунок часткового повернення в метаболічні ланцюги окисного фосфорилювання молекулярного кисню [16]. Особливістю ферменту $\epsilon$ те, що він має як каталазну, так i пероксидазну активність і міститься практично у всіх тканинах, найбільше в печінці, нирках [17]. Зростання активності каталази виявлено в гомогенаті стінки тонкої кишки (в 1,18 раза, $p<0,05)$ і печінці (в 1,13 раза, $p<0,05)$ (табл. 1). Аналізуючи динаміку змін активності досліджуваних ензимів у тканинах організму щурів, при застосуванні $1 \%$ розчину карагінану у питній воді протягом 1 місяця встановлено достовірно вищі показники СОД у тканинах тонкої кишки і печінки, проти каталази (рис. 1). При цьому коефіцієнт антиоксидантного захисту в стінці кишки становив $1,11(p<0,05)$, в міокарді - 1,0 і в печінці - 1,15 (p<0,05). Зростання співвідношення СОД/каталаза зумовлено зниженням активності каталази. 3 огляду на роль каталази в процесах оксигенації можна припустити, що тканини тонкої кишки і печінки перебувають у стані гіпоксії. Накопичення гідрогену пероксиду через недостатню активність каталази, в свою чергу, зумовлює появу гідропероксидів ліпідів й окиснювальної модифікації білків.

Таблиця 1. Показники ензимної ланки антиоксидантної системи захисту у стінці тонкої кишки, серці та печінці

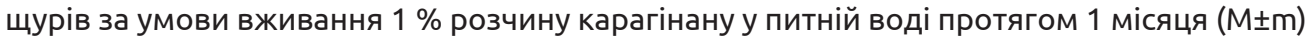

\begin{tabular}{|l|c|c|}
\hline \multicolumn{1}{|c|}{ Показник } & $\begin{array}{c}\text { Контрольна група } \\
(\mathrm{n=12})\end{array}$ & $\begin{array}{c}\text { Дослідна група } \\
\text { (n=12) }\end{array}$ \\
\hline \multicolumn{3}{|c|}{ Тканини стінки тонкої кишки } \\
\hline СОД, ум.од./мг білка & $37,17 \pm 1,47$ & $48,97 \pm 1,66^{*}$ \\
\hline Каталаза, кмоль $\mathrm{H}_{2} \mathrm{O}_{2} /$ хв на 1 мг білка & $3,92 \pm 0,12$ & $4,63 \pm 0,12^{*}$ \\
\hline \multicolumn{3}{|c|}{ Тканини міокарда } \\
\hline СОД, ум.од./мг білка & $45,63 \pm 1,29$ & $49,68 \pm 0,73$ \\
\hline Каталаза, кмоль $\mathrm{H}_{2} \mathrm{O}_{2} /$ хв на 1 мг білка & $10,23 \pm 0,20$ & $11,13 \pm 0,19$ \\
\hline \multicolumn{2}{|c|}{ Тканини печінки } \\
\hline СОД, ум.од./мг білка & $73,13 \pm 1,69$ & $94,86 \pm 1,16^{*}$ \\
\hline Каталаза, кмоль $\mathrm{H}_{2} \mathrm{O}_{2} /$ хв на 1 мг білка & $114,93 \pm 1,04$ & $129,77 \pm 1,73^{*}$ \\
\hline
\end{tabular}

Примітка: * - відмінність достовірна стосовно контролю ( $p<0,05)$. 


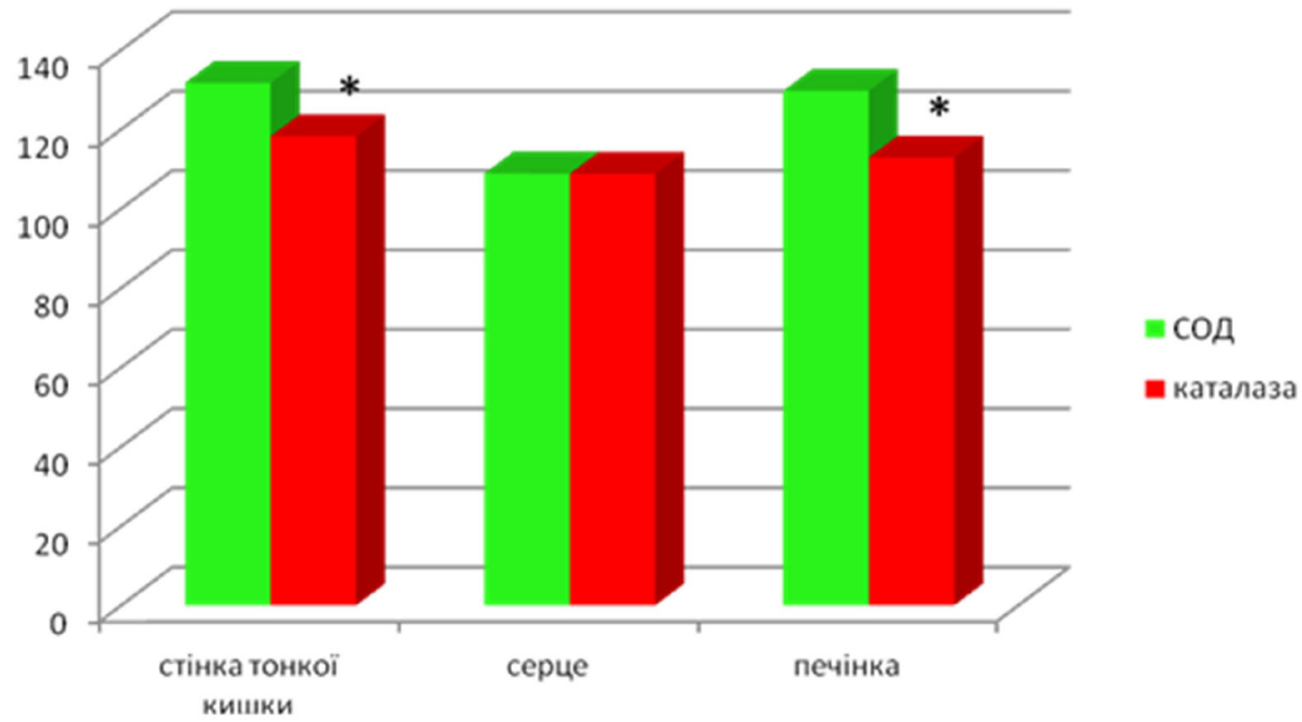

Рис. 1. Динаміка активності СОД і каталази у стінці тонкої кишки, серці та печінці щурів за умови вживання 1 \% розчину карагінану у питній воді протягом 1 місяця.

Висновки. Пероральне застосування 1 \% розчину карагінану щурам веде до статистично значимої активації ензимної ланки антиоксидантного захисту в стінці тонкої кишки і печінці, що характе-

\section{ЛІТЕРАТУРА}

1. Weiner M. L. Food additive carrageenan: Part II: a critical review of carrageenan in vivo safety studies / M. L. Weiner // Crit. Rev. Toxicol. - 2014. - № 44. P. 244-269.

2. Carrageenan induces interleukin-8 production through distinct Bcl10 pathway in normal human colonic epithelial cells / A. Borthakur, S. Bhattacharyya, P. K. Dudeja, J. K. Tobacman // Am. J. Physiol. Gastrointest. Liver Physiol. 2007. - No. 292. - P. G829-G838.

3. Carrageenan induces the disruption of intestinal epithelial caco-2 monolayers by promoting the interaction between intestinal epithelial cells and immune cells / H. Y. Jiang, F. Wang, H. M. Chen, X. J. Yank // Mol. Med. Rep. - 2013. - No. 8. - P. 1635-1642.

4. Bhattacharyya S. Molecular signature of kappacarrageenan mimics chondroitin-4-sulfate and dermatan sulfate and enables interaction with arylsulfatase B / S. Bhattacharyya, J. K. Tobacman // J. Nutr. Biochem. 2012. - No. 23. - P. 1058-1063.

5. Exposure to the common food additive carrageenan leads to glucose intolerance, insulin resistance and inhibition of insulin signaling in HepG2 cells and C57BL/6J mice / S. Bhattacharyya, I. O. Sullivan, S. Katyal [et al.] // Diabetologia. - 2012. - No. 55. - P. 194-203.

6. Агаева Р. К. Свободнорадикальное окисление в тканях тонкой кишки, легких и печени при ожоговом шоке / Р. К. Агаева, И. А. Фастова // Медицинский вестник Башкортостана. - 2009. - С. 113-115.

7. Moyana T. N. Carrageenan-induced intestinal injury in the rat - a model for inflammatory bowel disease / T. N. Moyana, J. M. Lalonde // Ann. Clin. Lab. Sci. - 1990. Vol. 20 (6). - P. 420-426. ризується підвищенням, відповідно, активності СОД (на 31,8 \% і 29,7 \%) і каталази (на 18,3 \% і $12,9 \%) \mathrm{p}<0,05$.

8. Пат. 97322. Україна, МПК: G09B 23/28. Спосі6 моделювання хронічного гастроентероколіту / Г.І.ГубінаВакулик, Н. Г. Колоусова, Т. О. Іваненко, Т. В. Горбач, В. О. Коробчанський ; власник Харківський нац. мед. ун-т. № а201014510; заявл. 06.12.2010 ; опубл. 25.01.2012, Бюл. № 2. -4 c.

9. Nesterova L. A. Characterization of specific binding blocker $[+\mathrm{H}]$-quinuclidinylbenzilate $\mathrm{M}$-cholinergic receptors in rat brain cortex membranes / L. A. Nesterova, E. A. Smurova, B. N. Manukhin // Reports of the Academy of Sciences. - 1995. - No. 343 (2). - P. 268-271.

10. Lowry O. H. Protein measurement with the Folin phenol reagent / O. H. Lowry // Journal of Biological Chemistry. - 1951. - No. 193(1). - P. 404-415.

11. Казимирко В. К. Антиоксидантная система и ее функционирование в организме человека / В. К. Казимирко, В. И. Мальцев // Здоровье Украины. - 2004. № 98. - С. 40-45.

12. Метод определения активности каталазы / М. А. Королюк, А. И. Иванова, И. Г. Майорова, В. Е. Токарев // Лаб. Дело. - 1988. - № 1. - С. 16-19.

13. Гланц С. Медико-биологическая статистика : пер. з англ. / С. Гланц. - М. : Практика, 1999. - 459 с.

14. Реброва О. Ю. Статистический анализ медицинских данных. Применение пакета прикладных программ STATISTICA / О. Ю. Реброва. - М. : МедиаСфера, 2002. -312 c.

15. Glutathione peroxidase, superoxide dismutase, and catalase inactivation by peroxides and oxygen derived free radicals / E. Pigeolet, P. Corbisier, A. Houbion [et al.] // Mech Ageing Dev. - 1990 - Vol. 51, No. 3. P. 283-297. 
Огляди літератури, оригінальні дослідження, погляд на проблему

16. Сторожук П. Г. Ферменты прямой и косвенной антирадикальной зашиты эритроцитов и их роль в инициации процессов оксигенации гемоглобина, антибактериальной защите и делении клеток / П. Г. Сторожук // Вестник интенсивной терапии. - 2003. - № 3. - С. 8-13.
17. Криницька І. Я. Функціональний стан системи антиоксидантного захисту крові у щурів з модельованим гепатопульмональним синдромом / І. Я. Криницька // Медична хімія. - 2013. - Т. 15, № 1. - С. 34-39.

\section{REFERENCES}

1. Weiner, M.L. (2014). Food additive carrageenan: Part Il: a critical review of carrageenan in vivo safety studies. Crit. Rev. Toxicol., 44, 244-269.

2. Borthakur, A., Bhattacharyya, S., Dudeja, P.K., \& Tobacman, J.K. (2007). Carrageenan induces interleukin-8 production through distinct Bcl10 pathway in normal human colonic epithelial cells. Am. J. Physiol. Gastrointest. Liver Physiol., 292, G829-G838.

3. Jiang, H.Y., Wang, F., Chen, H.M., \& Yank, X.J. (2013). Carrageenan induces the disruption of intestinal epithelial caco-2 monolayers by promoting the interaction between intestinal epithelial cells and immune cells. Mol. Med. Rep., 8, 1635-1642.

4. Bhattacharyya, S., \& Tobacman, J.K. (2012). Molecular signature of kappa-carrageenan mimics chondroitin4-sulfate and dermatan sulfate and enables interaction with arylsulfatase B. J. Nutr. Biochem., 23, 1058-1063.

5. Bhattacharyya, S., Sullivan, I.O., Katyal, S., Unterman, T., \& Tobacman, J.K. (2012). Exposure to the common food additive carrageenan leads to glucose intolerance, insulin resistance and inhibition of insulin signaling in HepG2 cells and C57BL/6J mice. Diabetologia, 55, 194-203.

6. Agaeva, R.K., \& Fastova, I.A. (2009). Svobodnoradikalnoe okislenie $v$ tkanyah tonkoy kishki, legkikh i pecheni pri ozhogovom shoke [Free radical oxidation in the tissues of the small intestine, lungs and liver with burn shock]. Meditsinskiy vestnik Bashkortostana - Medical Journal of Bashkortostan, 113-115 [in Russian].

7. Moyana, T.N., \& Lalonde, J.M. (1990). Carrageenaninduced intestinal injury in the rat - a model for inflammatory bowel disease. Ann. Clin. Lab. Sci., 20, 6, 420-426.

8. Hubina-Vakuliuk, H.I., Kolousova, N.H., Ivanenko, T.O., Horbach, T.V., \& Korobchanskyi, V.O. (2012). Sposib modeliuvannia khronichnoho hastroenterokolitu [Method of modeling chronic gastroenterocolitis]. Patent Ukraina, № a201014510 [in Ukrainian].

9. Nesterova, L.A., Smurova, E.A., Manukhin, B.N. (1995). Characterization of specific binding blocker [+H]quinuclidinylbenzilate $\mathrm{M}$-cholinergic receptors in rat brain cortex membranes. Reports of the Academy of Sciences, 343 (2), 268-271.

10. Lowry, O.H. (1951). Protein measurement with the Folin phenol reagent. Journal of Biological Chemistry, 193 (1), 404-415.

11. Kazimirko, V.K., \& Maltsev, V.I. (2004). Antioksidantnaya sistema i ee funktsionirovanie $v$ organizme cheloveka [Antioxidant system and its functioning in the human body]. Zdorovye Ukrainy - Health of Ukraine, 98, 40-45 [In Ukrainian].

12. Korolyuk, M.A., Ivanova, A.I., Mayorova, I.G., Tokarev, V.E. (1988). Metod opredeleniya aktivnosti katalazy [Method for determination of catalase activity]. Lab. DeloLaboratory Case, 1, 16-19 [In Russian].

13. Glanc, S. (1999). Mediko-biologicheskaya statistika [Medical and Biological Statistics]. Moscow: Praktika [in Russian].

14. Rebrova, O.Yu. (2002). Statisticheskiy analiz meditsinskikh dannykh. Primenenie paketa prikladnykh programm STATISTICA [Statistical analysis of medical data. Application of software package STATISTICA]. Moscow: MediaSfera [in Russian].

15. Pigeolet, E., Corbisier, P., Houbion, A., \& Lambert, D. et al. (1990). Glutathione peroxidase, superoxide dismutase, and catalase inactivation by peroxides and oxygen derived free radicals. Mech. Ageing Dev., 51, 3, 283-297.

16. Storozhuk, P.G. (2003). Fermentyi pryamoy i kosvennoy antiradikalnoy zashchity eritrotsitov $\mathrm{i}$ ikh rol $v$ initsiatsii protsessov oksigenatsii gemoglobina, antibakterialnoy zashchite i delenii kletok [Enzymes of direct and indirect antiradical protection of erythrocytes and their role in initiating processes of oxygenation of hemoglobin, antibacterial protection and cell division]. Vestnik intensivnoy terapii Journal of Intensive Care, 3, 8-13 [in Russian].

17. Krynytska, I.Ya. (2013). Funktsionalnyi stan systemy antyoksydantnoho zakhystu krovi u shchuriv z modelovanym hepatopulmonarnym syndromom [Functional state of the system of antioxidant blood defense in rats with simulated hepatopulmonary syndrome]. Medychna khimiia - Medical Chemistry, 15, 1, 34-39 [in Ukrainian]. 


\title{
АКТИВНОСТЬ СУПЕРОКСИДДИСМУТАЗЫ И КАТАЛАЗЫ В СТЕНКЕ ТОНКОЙ КИШКИ, СЕРДЦЕ И ПЕЧЕНИ ПРИ ЭКСПЕРИМЕНТАЛЬНОМ ПРИМЕНЕНИИ КАРРАГИНАНА
}

\section{๑о. М. Копаница}

\author{
Ровенский государственный базовый медицинский колледж
}

РЕЗЮМЕ. Введение. Одним из ведущих механизмов формирования синдрома органных дисфункций при различных патологиях является гиперпродукция активных форм кислорода, которые запускают процессы перекисного окисления в органах и тканях, удаленных от очага поражения. Возникновение оксидативного стресса обусловлено также снижением эффективности антиоксидантной защиты.

Цель исследования - установить активность супероксиддисмутазы и каталазы в тканях тонкой кишки, сердца и печени животных при применении 1 \% раствора к-карагинана.

Материал и методы. Исследование проведено на 24 белых нелинейных самцах-крысах. Животным опытной группы обеспечивали свободный доступ к 1,0 \% раствору карагинана в воде в течение 1 месяца. В отобранных образцах тонкой кишки, сердца и печени крыс оценивали активность супероксиддисмутазы и каталазы.

Результаты. Установлено, что применение 1 \% раствора к-карагинана в воде приводило к активации энзимного звена антиоксидантной системы защиты крыс. Установлено повышение активности СОД в гомогенате стенки тонкой кишки (в 1,32 раза, $\mathrm{p}<0,05)$ и печени (в 1,30 раза, $\mathrm{p}<0,05)$. Повышалась также активность каталазы в гомогенате стенки тонкой кишки (в 1,18 раза, $p<0,05)$ и печени (в 1,13 раза, $p<0,05)$. При этом коэффициент антиоксидантной защиты в стенке кишки составил 1,11 ( $<<0,05)$, в миокарде $-1,0$ и в печени $-1,15$ ( $p<0,05)$.

Выводы. Пероральное применение 1 \% раствора карагинана крысам ведет к статистически значимой активации энзимного звена антиоксидантной защиты в стенке тонкой кишки и печени, которая характеризуется повышением, соответственно, активности СОД (на 31,8 \% и 29,7 \%) и каталазы (на 18,3 \% и 12,9 \%), p<0,05.

КЛючЕВЫЕ СЛОВА: крысы; каррагинан; антиоксидантная защита.

\section{SUPEROXIDE DISMUTASE AND CATALASE ACTIVITY IN THE SMALL INTESTINE WALL, HEART AND LIVER IN EXPERIMENTAL APPLICATION OF CARRAGEENAN}

๑O. M. Kopanytsia

\section{Rivne State Basic Medical College}

SUMMARY. Introduction. One of the leading mechanisms of organ dysfunction syndrome formation in various pathologies is the hyperproduction of active forms of oxygen, which triggers the processes of peroxide oxidation in organs and tissues far from the focal point of injury. Occurrence of oxidative stress is also caused by a decrease in the effectiveness of antioxidant protection.

The aim of the study - to determine the activity of superoxide dismutase and catalase in the tissues of the small intestine, myocardium and liver of experimental animals using $1 \%$ carrageenan solution.

Materials and Methods. The study was carried out on 24 white non-linear male rats. The animals of the experimental group were provided with free access to a $1.0 \%$ of carrageenan solution for 1 month. In the selected samples of the small intestine, heart and liver was evaluated the activity of superoxide dismutase and catalase.

Results. It was established that the use of $1 \%$ solution of k-carrageenan in drinking water caused the activation of the enzyme level of the antioxidant defense system. An increase in the activity of SOD in the wall homogenate of the small intestine (by 1.32 times, $p<0.05)$ and in the liver $(1.30$ times, $p<0.05)$ was observed. The activity of catalase in the wall of the small intestine homogenate (by 1.18 times, $p<0.05)$ and in the liver $(1.13$ times, $p<0.05)$ also increased. At the same time, the coefficient of antioxidant protection in the intestine wall was $1.11(p<0.05)$, in the myocardium - 1.0 and in the liver $-1.15(p<0.05)$.

Conclusions. Oral administration of a $1 \%$ carrageenan solution in experimental animals leads to statistically significant activation of the enzyme level of antioxidant defense in the wall of the small intestine and liver, which is characterized by an increase, respectively, in the activity of SOD (31.8 \% and $29.7 \%$ ) and catalase (18.3 \% and $12.9 \%)$, $p<0.05$.

KEY WORDS: rats; carrageenan; antioxidant protection. 